\title{
Impacts of sustainable value and business stewardship on lifestyle practices in clothing consumption
}

\author{
Stacy Hyun-Nam Lee ${ }^{1^{*}}\left(\mathbb{D}\right.$, HaeJung Kim² ${ }^{2}$ and Kiseol Yang ${ }^{2}$
}

*Correspondence:

shlvf6@mail.missouri.edu

${ }^{1}$ Department of Textile

and Apparel Management,

University of Missouri, 137

Stanley Hall, Columbia, MO

65211, USA

Full list of author information is available at the end of the article

\begin{abstract}
With a rising interest in the sustainable issue on the part of society and industry, comprehending the dynamics of the sustainable phenomenon can empower marketers and researchers to devise effective marketing strategies and advance theoretical knowledge for the fashion and textile discipline. While consumer sustainable lifestyle practices and business stewardship implementation have been neglected in the fashion and textiles industries, this study aims to test the sustainable VALS framework by identifying the sustainable value and lifestyle practices, and examining the impacts of business stewardship on consumer sustainable practices. The results of the data $(n=239)$ from a US university identified feasible dimensions of sustainable value, lifestyle practices, and business stewardships. Upon testing multiple regression analysis for the sustainable VALS framework, all 12 hypotheses were supported to validate the significant impacts of sustainable values and business stewardship on the consumers' practices of a sustainable lifestyle on fashion product consumption. Specifically, altruistic, openness to change, anthropocentrism, and ecocentrism values are of interest; and the business stewardship of eco-labels and CSR drives play pivotal roles in promoting consumers' sustainable lifestyle practices.
\end{abstract}

Keywords: Business stewardship, Sustainable lifestyle, Value, VALS framework

\section{Introduction}

The Lifestyles of Health and Sustainable (LOHAS) consumers, who desire to lead sustainable lifestyle and fulfill their responsibility to help protect the environment, are a significant consumer segment for products and services focused on health, the environment, social justice, personal development, and sustainable living (Yeh and Chen 2011). This specific segment consists of $30 \%$ of the American, Japanese, and European populations representing an estimated $\$ 340$ billion US market and a $\$ 546$ billion market worldwide (Emerich 2000). Comparable sustainable-oriented consumer segments such as Good Neighbors, Tree Huggers, and Eco-Village also facilitate diverse behaviors of energy saving, recycling, and green consumption beyond conventional behavioral boundaries (Barr and Gilg 2006). Indeed, sustainable lifestyle societies have gained much attention from society as well as business because they motivate environmentally

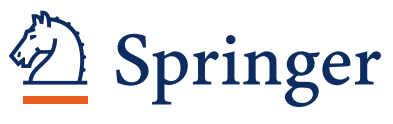

(c) 2015 Lee et al. This article is distributed under the terms of the Creative Commons Attribution 4.0 International License (http:// creativecommons.org/licenses/by/4.0/), which permits unrestricted use, distribution, and reproduction in any medium, provided you give appropriate credit to the original author(s) and the source, provide a link to the Creative Commons license, and indicate if changes were made. 
conscious consumerism, change consumers' lifestyle practices, and shift the profitdriven business paradigm toward a socially responsible orientation (Chapin et al. 2009).

By virtue of this orientation to sustainable, the fashion and textiles industry has begun to move towards the adoption of a sustainable business framework (Holgar et al. 2009). Recently, business stewardship, a sustainable business framework, aims at supporting humans' well-being and preventing harm effects on the environment (Chapin et al. 2009) by employing CSR drives and ecological labels and indices. Business stewardships of Edun, Stella McCartney, Katherine Hamnett, Noir, and American Apparel have increased public awareness (Holgar et al. 2009) based on their sustainable education and market positioning strategies. Corporate social responsibility (CSR) drives are an evocative business stewardship focusing on labor standards, human rights, and the environment (Husted and Allen 2000). For instance, So-Me and EDUN raised awareness for the causes of solidarity and pacifism through their fashion products (Poldner 2010). Business stewardship by means of eco-labeling/indices convey the specific information regarding the environmental impacts of a product (Bruce and Laroiya 2006). HEM, Gap and Marks E Spencer have launched a universally-recognized product labeling which informs the environmental impact (DiCamillo 2009). However, these business efforts of business stewardship are often fragmented, and this leaves consumers and companies in doubt as to whether the current stewardship efforts are useful to society, business and consumers.

The environmental impact of the fashion industry has become increasingly detrimental as a result of an increased level of resource exploitation, pollution, and waste due to consumer demand for an accelerated cycle of new fashion (O'Cass 2004). While fashion firms are adopting business stewardship practices, consumers seem to be lagging behind to adopt or change to sustainable lifestyle (Thørgerson and Crompton 2009). This reluctance of consumers raises questions about the effectiveness of current business stewardships. There is a clear need for additional research on consumer psychology and social acceptance in conjunction with business accountability to bridge the gap between business stewardship and consumer demand for this business effort (Kahle and Gurel-Atay 2013).

Based on a theoretical investigation of values and lifestyle concepts beyond demographic and socio-economic characteristics, Mitchell (1983) describes consumer behavior variation in terms of the Values and Lifestyles Scale (VALS). In line with the VALS perspective (Mitchell 1983), this study develops the "Sustainable VALS framework" by incorporating into it business stewardship efforts on the part of corporations. First, sustainable VALS makes the notion of sustainable value, which consists of social value and environmental value (Nordlund and Garvil 2002; Stern et al. 1993). Sustainable values are clearly held by committed environmentalists who hold values emphasizing social unity more than personal wealth (Barr and Gilg 2006). Second, lifestyle scale is extended to six practice domains in line with activities, interests, and opinion of fashion product consumption. Third, business stewardship is specified emphasizing the business effort for CSR drives and eco-label/index. Lastly, our study specifically aimed to explore sustainable lifestyle, values, and awareness of stewardship among college students because college students spend about $\$ 6$ billion annually on clothing and footwear in the US, accounting for $10 \%$ of their total purchases (Seckler 2005; Crane 2007). Furthermore, 
Yan and Chang (2008) placed an importance of college students' consumer socialization because classes and student organization memberships could possibly change college students' views of the environment and knowledge of environmentally friendly actions.

To gain theoretical and practical insights on sustainable VALS (value and lifestyle stewardship), this study explores the influences of sustainable values and business stewardship on consumer's sustainable lifestyle perception. The objectives of the study are: (1) to identify the dimensionality of sustainable value, sustainable stewardship, and sustainable lifestyle practices from consumers' perspective; and (2) to examine the impacts of sustainable value and stewardship on sustainable lifestyle practices. Given the exponential growth of the sustainable phenomenon, comprehending the dynamics influencing lifestyle practices can empower marketers and researchers to devise effective marketing strategies and to identify practical applications for further research.

\section{Literature review}

\section{Sustainable lifestyle practices}

Lifestyle is related to the general attitudes associated with consumers' general activities, interest, and opinions (AIO) (Harcar and Kaynak 2007). Lifestyle influences the purchase decision and consumption behavior, and relates to consumerism (Chu and Chan 2008). Thus, lifestyle can be viewed as an interpretive framework for the construction of social reality (Yeh and Chen 2011). Upon acquiring explicit knowledge of how specific activities affect society (Buenstorf and Cordes 2008), consumers likely pursue behavior participations such as consuming green products, recycling, considering clothing care, and adopting eco-friendly behavior (McDonald and Oates 2006). For instance, sustainable lifestyle societies, such as LOHAS, Good Neighbors, Tree Huggers, and Eco-Village, are actively engaged in a broad range of practices based on environmental considerations and seek to make these considerations apply as legitimate rules within the society (Spaargaren 2003). These environmental engagements can be a motivator which results in moral obligation (Vining and Ebreo 1992). Although many researchers propose holistic frameworks of sustainable behaviors, what determines the sustainable behaviors and how sustainable behaviors can be changed (Steg and Vlek 1997) are confounded. Consumer involvement in sustainable lifestyles is of particular interest in the clothing and textile industry because it might imply the need for changes in the business paradigm toward promoting sustainable consumption, purchasing, and disposing. Hence, this study reviews six sustainable lifestyle practices along with consumers' activities, interests, and opinion (hereafter AIO).

\section{Green purchase intention}

Green intention are aware of and interested in environmental issues (Soonthonsmai 2007) and further purchase products related to environmental friendly (Chan 2001). Consumers purchase green textiles and clothes when their needs for performance, quality, convenience, and affordability are met and when they understand how a green product can help to solve environmental problems (Ottman 1992). There is a belief that socially conscious consumers contribute to improving environmental quality by purchasing environmentally friendly green products (Abdul-Muhmin 2007). 


\section{Recycling}

Recycling, which turns waste materials and clothing into valuable resources, is a vital component of sustainable lifestyle (Morgan and Birtwistle 2009). Recycling in the textile and clothing industry offers companies important benefits, particularly from an environmental viewpoint (Morgan and Birtwistle 2009). Newbery and Ghosh-Curling (2011) argue that consumers donate clothing and fashion items to protect the environment as well as to uphold their social and environmental values. These recycling practices stimulate manufacturers to increase supplies by producing high-quality recycled products. A study by Koch and Domina (1999) found that respondents chose most common options to recycle their clothing through organizations, such as Salvation Army and Goodwill, or passing on to family and friends. Koch and Domina (1999) asserted that altruistic concern (e.g. helping others and raising money for a cause) could be the primary motivation of donations among consumers. However, they also addressed lack of knowledge for textile and apparel products recycling could limit consumers to participate in recycling textile and apparel waste.

\section{Clothing care}

Clothing care perceives as one of the useful practices of sustainable lifestyle (Dickson et al. 2009). Consumer-uses, such as washing, and drying of T-shirts made from conventional cotton, waste more energy compared to the energy used during disposal and manufacturing (Dickson et al. 2009). Several studies argue that consumer product care consumes more energy than all other parts of clothing's life cycle (Spaargaren 2003). However, consumers are unaware that water temperature has an environmental impact and think that washing machines need to be full of water to wash effectively (Newbery and Ghosh-Curling 2011). If company stewardship practices provide the relevant information by means of eco labels that reflect consumers' social and environmental values (Dickson et al. 2009), consumers should be willing to participate sustainable clothing care.

\section{Eco-citizenship}

Eco-citizenship is a shared personal commitment to sustainable (Dobson 2003; Seyfang 2006) which eludes the restrictive financial considerations commonly associated with efforts to reduce the impacts of consumption decisions. Researchers (Dobson 2003; Harcar and Kaynak 2007; Seyfang 2006) find that ecological citizens ascribe to a sense of environmental responsibility on a planetary scale which is adopted in their daily lives to reduce unjust impacts on others, for instance, by considering the implications of daily routine purchasing decisions and changing their behavior accordingly. Eco-citizenship is greatly affected by environmental consciousness and concern for the collective good, which become part of consumers' values in decision making and may cause consumers to positively respond to a company's stewardship efforts (Fraj and Martinez 2006).

\section{Fair trade}

Fair trade is defined as trading partnerships that aim to achieve the sustainable development of disadvantaged producers in the Third World (Krier 2001). Currently, as a result of marketing via many channels in various categories, fair trade products' sales have 
risen steadily throughout the world (Fairtrade Labelling Organizations International 2010). However, consumers perceive that the price of fair trade products is expensive while the quality and quantity of information on fair trade products are imperfect (De Pelsmacker et al. 2005). As businesses and society make an effort to educate consumers about the impacts of fair trade practices and increase companies' stewardship efforts such as eco-labeling and CSR drives, consumers will modify their social and environmental values and encourage more fair trade practices (Krier 2001).

\section{Pro-environmentalism}

Pro-environmentalism refers to sustainable opinion that is mainly determined by attitudinal variables including values, beliefs, and norms (Nordlund and Garvill 2002). Proenvironmental consumers often concern about the environment, and verbally endorse most products that seek to conserve or improve environment (McDonald and Oates 2006). Though, consumers are reluctant to share pro-environmentalism unless they hold the belief that consumers' efforts can make a difference to the environment (Pieters et al. 1998). Apparently, pro-environmentalism focuses on opinion that contribute to consumers' moral obligation, values, and beliefs.

\section{Sustainable value}

Values are of particular interest because values may affect a wide spectrum of behavior (Seligman et al. 1996; Soyez 2012), consumer decision processes (Vermeir and Verbeke 2006), and attitudes, with diverse emotional intensity (Dietz et al. 2005). Values can be categorized as social and environment values (Stern et al 1999; Thomson and Barton 1994; Van Vugt and Samuelson 1999). Given individuals' relation to the natural environment and to society, many scholars (Karp 1996; Stern and Dietz 1994; Stern et al. 1995; Dietz et al. 2005; Steg and Vlek 2009) suggest a conception of sustainable value with an emphasis on the intrinsic nature of that value. Sustainable values are clearly held by committed environmentalists who hold values emphasizing social unity more than personal wealth (Barr and Gilg 2006). The choice between acting in accordance with one's self-interest and acting in the interest of the collective has often been defined as a social dilemma, because pro-environmental behavior may require the individual to restrain egoistic tendencies for the benefit of others (Vining and Ebreo 1992; Stern et al. 1995: Soyez 2012). Schultz (2001) identifies three value orientations termed social-altruistic, self-enhancement, and biospheric, which are comparable to Merchant's (1992) three "ethics" of the homocentric, ecocentrism, and egocentric. Biospheric values are prominent in the thinking of many ecologists and environmentalists (Stern and Dietz 1994). Biospheric value emerges from the concepts of anthropocentrism and ecocentrism, in which take phenomena on the basis of costs or benefits to ecosystems, and significantly determine pro-environmental behaviors (Schultz 2001). To examine how sustainable values influence sustainable lifestyle practices, this study employs the notion of three types of values: altruistic, ecocentrism and anthropocentrism.

\section{Altruistic}

Altruistic value (or self-transcendence) consists of universalism and benevolence, which entail concerns for the welfare and interests of others (Davidov et al. 2008). People's 
behavior based on social-altruistic values comes with moral imperatives such as the Golden Rule (treating others as you would have them treat you) (Stern et al. 1993). Stern et al. (1995) argue that environmentalists are prone to present with both altruistic and open to change values. People with altruistic values bring about benefits for humans as well as other species by becoming advocates for companies that practice sustainable practices (Schultz 2001). Consumers with altruist values are in favor of undertaking environmental actions because environmentally conscious consumers hold values that emphasize unity more than personal wealth (Barr and Gilg 2006). Greater evidence of sustainable lifestyle practices is revealed among altruistic as opposed to egoistic or competitive social value orientations (Van Vugt and Samuelson 1999).

\section{Anthropocentrism}

Anthropocentrism represents the belief that environmental protection is important because of nature's contribution to human welfare (Nordlund and Garvill 2002). Values underlying anthropocentrism are human-centered (Nordlund and Garvill 2002) and can be found in societies where people share similar interests and commitment towards sustainable. They aim for a rationale for changing behavior towards more sustainable lifestyles motivated by an ethical position, rather than simply responding to superficial incentives (Seyfang 2006).

\section{Ecocentrism}

Ecocentrism is the belief that the ecosystem has an intrinsic value and that this alone is reason enough to protect it (Nordlund and Garvill 2002). Given incremental environment issues, ecocentrism consumers are less concerned with material wealth and personal influence: they hold values that place nature in an equal position with humans and believe that nature has critical limits which must not be crossed by human development (Thogersen and Grunert-Beckmann 1997). The following hypotheses between sustainable values and six sustainable practices are tested:

H1-H6: Sustainable consumer value (a: Altruistic: b: Anthropocentrism; and c: Ecocentrism) positively affects Sustainable lifestyle Practices (H1: Green purchase intention; H2: Recycling; H3: Clothing care; H4: Eco-citizenship; H5: Fair trade; and H6: Pro-environmental attitude).

\section{Business stewardship}

Stewardship is defined as the responsible use of resources that takes into account the interests of society and future generations, as well as accepting significant accountability for the private citizen to society (Worrell and Appleby 2000). The notion of stewardship argues that the corporate sphere has greater responsibility to the environment and the society than an individual consumer. In response to increasing interest from society, government, and consumers, corporate stewardship has undergone a modernization in regard to the ethical CSR aspects balanced among people, planet, and profit. This study adapts business stewardship focusing specifically on companies' eco-label/index system and the CSR drives. 


\section{Eco-label/index}

Eco-label/index refers to a market technique for conveying information about environmental protection (Bruce and Laroiya 2006). Eco-labels are based on multiple criteria covering a product's life cycle from the sourcing of the raw materials, production methods, and consumption to disposal (Joshi 2004). However, consumers find eco-labels/ indices neither useful nor informative because eco-labels/indices are difficult to verify firms' claims and performances regarding the environment (Thogersen 2000). Recently, several large companies and government agencies have announced or improved their green- or eco-labeling (Kim and Damhorst 1999). With standardized eco-labels/indices, consumers are willing to pay a premium price for eco-labeled products (Moon et al. 2002).

\section{Corporate social responsibility (CSR) drives}

CSR refers to a company's commitment to minimize any harmful effects and maximize their long-term beneficial impact on society (Mohr et al. 2001). Smith and Alcorn (1991) have found that socially conscious consumers are likely to switch brands to support companies that make donations, and those consumers purchase products for charitable causes. Kozar and Hiller Connell (2010) conducted a study and found that $27 \%$ of participants had boycotted an apparel retailer in the past because of sweatshop abuses while $33 \%$ indicated that a firm's treatment of workers influenced their purchasing behavior. Socially active consumers have a positive image of firms practicing cause marketing, and may change brands or retailers to support these companies (Mohr et al. 2001).

However, Kozar and Hiller Connell (2010)'s findings supported previous studies (Carrigan and Attalla 2001; Dickson 1999; Kim and Damhorst 1998) that only $36 \%$ of participants were shown a willingness to pay premium prices for socially responsible goods, and $14 \%$ inquired about companies' labor conditions and information prior to making purchasing decisions. Based on this perspective, this study tests the following relationships between two stewardship and six sustainable practices:

H7-H12: Sustainable business stewardship (a: Eco-labels/Indices; and b: CRS drives) positively affects Sustainable lifestyle Practices (H7: Green purchase intention; H8: Recycling; H9: Clothing care; H10: Eco-citizenship; H11: Fair trade; and H12: Pro-environmental attitude).

Based on these hypotheses, the research framework is structured to explain how sustainable value and sustainable stewardship affect sustainable lifestyle practices (see Fig. 1).

\section{Method}

\section{Instruments}

A self-administered questionnaire was developed based on existing scales including sustainable values (Barr and Gilg 2006; Stern and Dietz 1994) and sustainable lifestyle practices (De Pelsmacker et al. 2005; Fraj and Martinez 2006; Gam 2011). Since there were no specific measurements existing for business stewardship, items were modified based on the existing research of Zaichkowsky (1985). Due to the multi-dimensional aspects and no unified definition of CSR drives (Margolis et al. 2007), this study intended to 


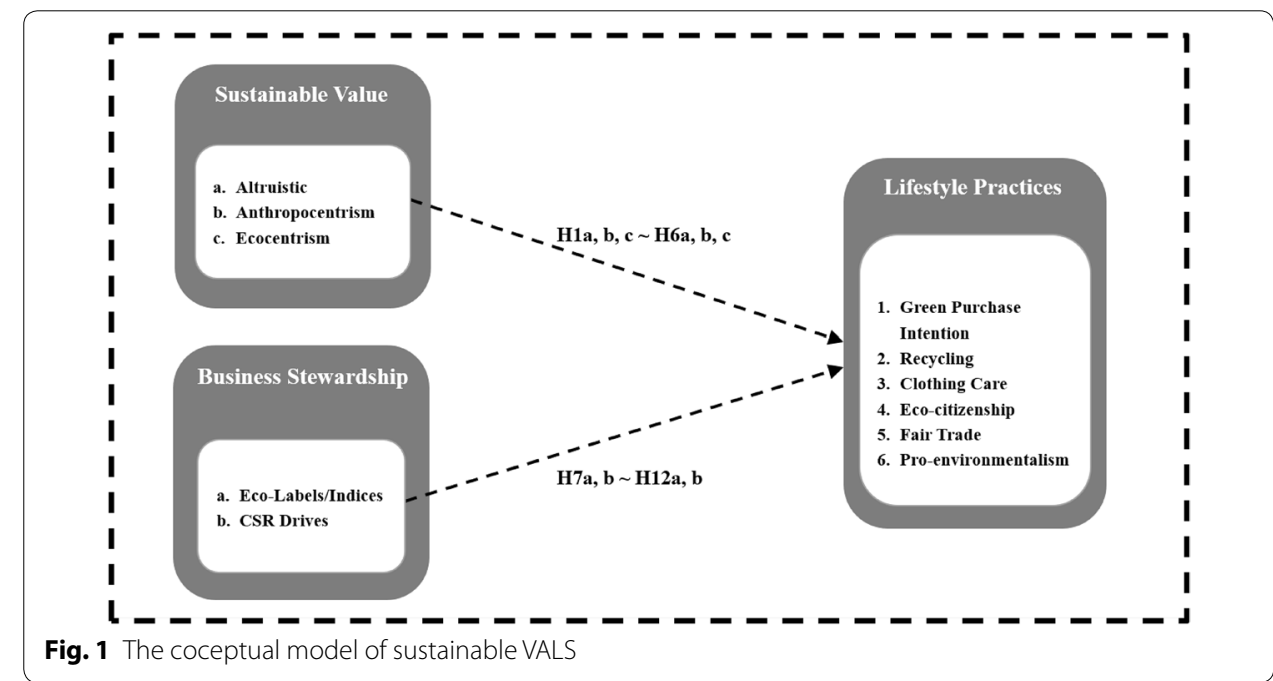

measure consumer awareness toward overall business green marketing and cause marketing since CSR drives encompass broader aspect of social and environmental responsibility (Raghubir et al. 2010). Minor changes were made to accommodate the context. All items were measured using a Likert scale ranging from strongly disagree (1) to strongly agree (6). The expert group from four faculty members in the merchandising discipline reviewed the content validity of the questionnaire items according to research variables. To test the internal validity and construct reliability of variables, a pretest was conducted using a group of 22 students from a southwestern university. Minor adjustments were made based on student feedback to improve readability.

\section{Data collection}

According to Seckler (2005) and Crane (2007), college students spend about $\$ 6$ billion annually on clothing and footwear in the US, accounting for $10 \%$ of their total purchases. Although consumers under 25 years make 53.9 percent less income compared to the average annual income of older consumers, college students spent a significant higher proportion of their income for apparel products and services than did the older consumers (Boston Consulting Group 2012; Bureau of Labor Statistics 2013). Furthermore, early study by Ward (1974) reported that consumer behavior in terms of skills, knowledge and attitudes learn from their parents and friends, which result significant influence on decision making of young consumers (Lachance et al. 2003; Garrison and Gutter 2010). Similarly, Yan and Chang (2008) placed an importance of college students' consumer socialization because classes and student organization memberships could possibly change college students' views of the environment and knowledge of environmentally friendly actions. Besides, the younger generation has been shown to be receptive to the influence of business stewardship in their purchase decisions. They tend to switch from one brand to another, if the other brand is associated with a good cause (Cone Communications 2008). Our study specifically designed to explore sustainable lifestyle, values, and awareness of stewardship among college students. 
Data were collected from students who were at least 18 years of age and currently enrolled at a southwestern university. Students $(\mathrm{N}=239)$ from a broad range of majors (e.g., business, merchandising, music, engineering, and visual arts) participated in the study during regularly scheduled classes. Participants were informed in writing that those completing the questionnaire would remain anonymous, that completion was voluntary, and that extra credit points would be given for their completion of the survey within each participating class.

Questionnaires were electronically distributed to students $(n=239)$ during regularly scheduled online and offline courses. The sample was comprised of females $(73.6 \%)$ and males $(26.4 \%)$ with a median age of 21 years. Over $40 \%$ of respondents were Caucasian (42.9\%), over $30 \%$ were junior level (34.2\%), and over $30 \%$ were majoring in merchandising and hospitality (37.5\%). Mainly, respondents had part-time job positions (45.0\%) and had incomes of \$1000-\$4000 (84.5\%). One-third of the sample indicated shopping frequency at twice a month (27.9\%). For further analysis, the greater part of the sample ( $\mathrm{n}=177,73.8 \%$ ) had the experience of purchasing items in at least one category that was considered to be environmentally friendly. In the category of products, food ( $\mathrm{n}=177,73.8 \%)$ was the most purchased category while furniture $(\mathrm{n}=13,5.4 \%)$ was the least represented category among the purchases of respondents.

\section{Data analysis}

The multi-item scales were subjected to a series of exploratory factor analyses with varimax rotations to identify the underlying dimensions of sustainable lifestyle practices, sustainable value, and business stewardship. Cronbach's alpha was calculated to confirm the scale reliability and the average variance extracted (AVE) was calculated to check discriminant validity among constructs. The average variance extracted (AVE) ranged from .69 to .82 , exceeding the recommended level of .50 (see Table 1). Discriminant validity among constructs was confirmed by comparing AVE and the squared

Table 1 Correlation table

\begin{tabular}{|c|c|c|c|c|c|c|c|c|c|c|c|}
\hline & \multicolumn{11}{|c|}{ Correlations } \\
\hline & 1 & 2 & 3 & 4 & 5 & 6 & 7 & 8 & 9 & 10 & 11 \\
\hline 1. Green purchase intention & .82 & .00 & .00 & .00 & .00 & .00 & .00 & .07 & .03 & .18 & .07 \\
\hline 2. Recycling & .00 & .65 & .00 & .00 & .00 & .00 & .00 & .05 & .01 & .03 & .02 \\
\hline 3. Clothing care & .00 & .00 & .43 & .00 & .00 & .00 & .04 & .00 & .01 & .00 & .03 \\
\hline 4. Eco-citizen & .00 & .00 & .00 & .64 & .00 & .00 & .05 & .07 & .00 & .02 & .02 \\
\hline 5. Fairtrade & .00 & .00 & .00 & .00 & .65 & .00 & .05 & .02 & .05 & .01 & .08 \\
\hline 6. Pro-environmental attitude & .00 & .00 & .00 & .00 & .00 & .69 & .05 & .12 & .05 & .01 & .08 \\
\hline 7. Altruistic & -.06 & .06 & $20^{* *}$ & -.09 & $.23^{* *}$ & $.23^{* *}$ & .72 & .00 & .00 & .00 & .02 \\
\hline 8. Anthropocentric & $.26^{* *}$ & $.22^{* *}$ & .01 & $.26^{* *}$ & $.14^{*}$ & $.35^{* *}$ & .00 & .82 & .00 & .11 & .11 \\
\hline 9. Ecocentrism & $.17^{*}$ & .11 & .11 & .05 & $.22^{* *}$ & $.23^{* *}$ & .00 & .00 & .79 & .00 & .00 \\
\hline 10. Ecolabel & $.42^{* *}$ & $.16^{*}$ & .01 & $.45^{* *}$ & .12 & .09 & .03 & $.34^{* *}$ & $.17^{* *}$ & .72 & .00 \\
\hline 11. CSR & $.26^{* *}$ & $.13^{4}$ & $.19^{* *}$ & $.13^{*}$ & $.29 * *$ & $.28^{* *}$ & $.14^{*}$ & $.37^{* *}$ & $.28^{* *}$ & .00 & .69 \\
\hline
\end{tabular}

The diagonal "italic" numbers represent the AVE whether the lower diagonal is representing the correlation between each construct, and the upper are represent squared correlations

* Correlation is significant at the 0.05 level (2-tailed)

** Correlation is significant at the 0.01 level (2-tailed) 
correlations between the two constructs of interest. All AVEs for the constructs were greater than their squared correlations (Fornell and Larcker 1981) (see Table 1).

To examine the hypothesized relationships, multiple regression analysis was conducted using the enter method. The Variance Inflation Factor (VIF) was calculated to determine the effect of multicollinearity. A common cutoff threshold is a tolerance value of .10, which corresponds to a VIF value of above 10 (Hair et al. 1998; Neter et al. 1985). All VIF values were below 1.001, which were within an acceptable range.

\section{Results and discussion}

\section{Identification of underlying dimensions}

A principal component factor analysis revealed the underlying dimensions of sustainable lifestyle practices as green purchase intention, recycling, clothing care, eco-citizenship, fair trade, and pro-environmental attitude. Sustainable values were identified with altruistic, anthropocentrism and ecocentrism. Business stewardship consisted of eco-labels/ indices and CSR drives. All factor items and factor loadings are summarized in Tables 2, 3 and 4.

Sustainable lifestyle practice Six factors were revealed with a $69.55 \%$ total cumulative variance. Scale reliabilities were acceptable in that the scores ranged from .77 to .95 . Six factors presented as green purchase intention, clothing care, recycling, eco-citizenship, fair trade, and pro-environmental attitude. The respondents regarded "recycling" $(M=4.38)$ as the most important factor, followed by "pro-environmental attitude $(M=4.28)$, "clothing care" $(M=4.25)$, "fair trade" $(M=4.11)$, "green purchase intention" $(M=3.41)$, and "eco-citizenship" $(M=2.50)$. Sustainable value The factor analysis for sustainable value distinguished three dimensions including altruistic, anthropocentric, and ecocentric. Three factors accounted for $71.66 \%$ of the total variance. Cronbach's alphas were acceptable with ranges from .80 to .93 , suggesting the internal consistency of items within each factor. The respondents regarded "altruistic" $(\mathrm{M}=4.77)$ as a more important value followed by "anthropocentric" $(M=4.47)$ and "ecocentrism" $(M=4.37)$. Business stewardship The factor analysis for business stewardship revealed two dimensions classified as Eco-Labels/Indices and CSR Drive with $72.38 \%$ of cumulative explained variance. Scale reliabilities for the two factors were acceptable with scores from .91 to .95 . The respondents considered "CSR drive" $(M=3.52)$ as a more important dimension than "eco-labels/indices" $(\mathrm{M}=3.37)$ for business stewardship tools.

\section{Testing hypotheses}

The hypothesized relationships of $\mathrm{H} 1$ through H12, in which sustainable practices were tested, aligned with the subsets of independent variables. All results from regression frameworks are summarized in Table 4. To test Hypothesis 1, the three sustainable value dimensions were employed as independent variables, and green purchasing was employed as the dependent variable. The framework significantly explained green purchasing intention $\left(F=8.275, p<.001, R^{2}=.097\right)$, and anthropocentrism (H1b) and ecocentrism $(\mathrm{H} 1 \mathrm{c})$ were significant, which partially supported H1. Hypothesis 2 showed a significant effect of sustainable values on recycling practice $(F=4.859$, $p<.01, R^{2}=.060$ ). Anthropocentrism (H2b) was accepted, which partially supported H2. Hypothesis 3 , related to clothing care practice $\left(F=4.251, p<.01, R^{2}=.053\right)$ was 
Table 2 Results of sustainable lifestyle practices factor analysis

\begin{tabular}{|c|c|c|c|c|}
\hline Factor & Scale items & F.L. ${ }^{a}$ & E.V. $(\%)^{b}$ & $\alpha^{c}$ \\
\hline \multirow{6}{*}{$\begin{array}{l}\text { Green purchase } \\
\text { intention }\end{array}$} & I would pay more for eco-friendly clothing & 618 & 10.27 & .90 \\
\hline & I am willing to pay more for environmental products & .725 & & \\
\hline & I would buy organic clothing to support organic farming & .653 & & \\
\hline & $\begin{array}{l}\text { I am likely to purchase organic cotton apparel if I find a brand } \\
\text { or store that carries organic cotton apparel }\end{array}$ & .632 & & \\
\hline & I would seek out eco-friendly clothing & .598 & & \\
\hline & $\begin{array}{l}\text { I am willing to pay a higher price to support small growers } \\
\text { from third-world countries }\end{array}$ & .577 & & \\
\hline \multirow[t]{4}{*}{ Clothing care } & $\begin{array}{l}\text { I pay attention to electric consumption efficiency and energy } \\
\text { saving capabilities when buying a washing machine and/ } \\
\text { or drier }\end{array}$ & .658 & 5.34 & .77 \\
\hline & $\begin{array}{l}\text { I believe buying denim jeans for myself from socially responsi- } \\
\text { ble business is good }\end{array}$ & .535 & & \\
\hline & $\begin{array}{l}\text { I wash clothes with warm or cold water instead of using hot } \\
\text { water }\end{array}$ & .629 & & \\
\hline & $\begin{array}{l}\text { I only run the washing machine and dishwasher when } \\
\text { they are full to save energy }\end{array}$ & .694 & & \\
\hline \multirow[t]{6}{*}{ Recycling } & I recycle glass and paper & .483 & 7.65 & .84 \\
\hline & I often donate clothes to charity & .711 & & \\
\hline & I look for ways to reuse consumption goods & .605 & & \\
\hline & I would "band down" clothing in family & .528 & & \\
\hline & I save gift wrapping paper & .740 & & \\
\hline & I save cardboard boxes for later use & .692 & & \\
\hline \multirow[t]{10}{*}{ Eco-citizenship } & I have attended a meeting related to ecology & .713 & 16.02 & .93 \\
\hline & I subscribe to an ecology-focused publication & .753 & & \\
\hline & I have signed a petition related to ecology or the environment & .718 & & \\
\hline & $\begin{array}{l}\text { I have taken part in a protest or demonstration which relates to } \\
\text { environmental issues }\end{array}$ & .789 & & \\
\hline & I contribute money to an environmental group & .822 & & \\
\hline & I voluntarily wort for an environmental group & .840 & & \\
\hline & $\begin{array}{l}\text { I read and share opinions on blogs regarding environmental } \\
\text { issues }\end{array}$ & .812 & & \\
\hline & $\begin{array}{l}\text { I put a lot of effort into being aware of the environmental } \\
\text { aspects and impacts of my life }\end{array}$ & .528 & & \\
\hline & $\begin{array}{l}\text { I often read articles that address the environmental impacts of } \\
\text { companies and industry }\end{array}$ & .544 & & \\
\hline & $\begin{array}{l}\text { I make a point to stay up-to-date on changes in environmental } \\
\text { laws and regulations }\end{array}$ & 1.571 & & \\
\hline \multirow[t]{8}{*}{ Fair trade } & I am willing to buy fair trade clothing and textile products & .599 & 14.91 & .94 \\
\hline & $\begin{array}{l}\text { I believe more brands should offer of a wider assortment of fair } \\
\text { trade products }\end{array}$ & 709 & & \\
\hline & I believe fair trade products need to be lower priced & .669 & & \\
\hline & More recognizable packaging of fair trade products is needed & .856 & & \\
\hline & $\begin{array}{l}\text { It is necessary for there to be an explanation of terms, logos } \\
\text { and the meanings of fair trade }\end{array}$ & .846 & & \\
\hline & $\begin{array}{l}\text { More provision of labels and indices on the packaging of fair } \\
\text { trade products is necessary }\end{array}$ & .882 & & \\
\hline & More fair trade advertising is needed & .796 & & \\
\hline & $\begin{array}{l}\text { A guideline for ethical norms and codes for consumers should } \\
\text { be created }\end{array}$ & .708 & & \\
\hline
\end{tabular}


Table 2 continued

\begin{tabular}{|c|c|c|c|c|}
\hline Factor & Scale items & F.L. ${ }^{a}$ & E.V. $(\%)^{b}$ & $\alpha^{c}$ \\
\hline \multirow[t]{7}{*}{ Pro-environmental attitude } & I am willing to participate in preserving the environment & .707 & 11.92 & .90 \\
\hline & $\begin{array}{l}\text { I believe personal responsibility for environmental problems is } \\
\text { important }\end{array}$ & .775 & & \\
\hline & $\begin{array}{l}\text { I believe the moral obligation to help the environment is } \\
\text { important }\end{array}$ & .787 & & \\
\hline & $\begin{array}{l}\text { I believe in the standards and ethics of socially responsible } \\
\text { clothing businesses }\end{array}$ & .597 & & \\
\hline & $\begin{array}{l}\text { I trust environmental information provided by socially respon- } \\
\text { sible brands and businesses }\end{array}$ & .500 & & \\
\hline & I believe in the importance of personal social responsibility & .749 & & \\
\hline & $\begin{array}{l}\text { I am willing to change brand that represents environmental } \\
\text { friendly labels }\end{array}$ & .536 & & \\
\hline
\end{tabular}

Table 3 Results of sustainable value factor analysis

\begin{tabular}{|c|c|c|c|c|}
\hline Factor & Scale items & F.L. ${ }^{a}$ & E.V. $(\%)^{b}$ & $\alpha^{c}$ \\
\hline \multirow[t]{4}{*}{ Altruistic } & I respect equal opportunity for all & .827 & 21.30 & .88 \\
\hline & I value a world free of war and conflict & .768 & & \\
\hline & I like to correct injustice & .798 & & \\
\hline & I care for others who are weak and older & .693 & & \\
\hline \multirow[t]{7}{*}{ Anthropocentric } & I respect the earth and nature & .764 & 31.84 & .93 \\
\hline & I believe it is important to harmonize with other species and nature & .764 & & \\
\hline & I prefer to fit into nature rather than control nature & .781 & & \\
\hline & I like to protect the environment & .818 & & \\
\hline & I anticipate preserving nature & .815 & & \\
\hline & I try to prevent pollution & .658 & & \\
\hline & I believe in protecting natural resources & .604 & & \\
\hline \multirow[t]{4}{*}{ Ecocentric } & I consider the balance of nature is delicate and easily upset & .646 & 18.52 & .80 \\
\hline & I think the earth has a finite amount of space for all its inhabitants & .765 & & \\
\hline & I do not think plants and animals exist primarily for human use & .787 & & \\
\hline & $\begin{array}{l}\text { I think one of die most important reasons for conservation is to preserve } \\
\text { wild areas }\end{array}$ & .566 & & \\
\hline
\end{tabular}

$\mathrm{n}=239$; Scale range: $1=$ Strongly disagree; $6=$ Strongly agree

a Factor loading; ${ }^{b}$ explained variance; ${ }^{c}$ Cronbach's $\alpha$

significant, and only altruistic value (H3a) was accepted, which partially supported $\mathrm{H} 3$. The positive relationships proposed by Hypothesis $4\left(F=6.341, p<.001, R^{2}=.076\right)$ were accepted owing to the positive impacts of altruistic value $(\mathrm{H} 4 \mathrm{a})$ on eco-citizenship interest, which partially supported $\mathrm{H} 4$. Hypothesis 5 significantly explained fair trade $\left(F=10.411, p<.001, R^{2}=.120\right)$ with a positive impact of altruistic value (H5a), anthropocentrism $(\mathrm{H} 5 \mathrm{~b})$, and ecocentrism $(\mathrm{H} 5 \mathrm{c})$, which strongly supported $\mathrm{H} 5$. In the testing of Hypothesis 6, altruistic value (H6a), anthropocentrism (H6b), and ecocentrism (H6c) were positively related to pro-environmentalism $\left(F=22.099, p<.001, R^{2}=.224\right)$, which strongly supported H6. Examining the relationship between three sustainable value dimensions and six sustainable lifestyle practices, impacts of three sustainable values 
Table 4 Results of sustainable value factor analysis

\begin{tabular}{|c|c|c|c|c|}
\hline Factor & Scale items & F.L. ${ }^{a}$ & E.V. $(\%)^{b}$ & $\alpha^{c}$ \\
\hline \multirow[t]{10}{*}{ Eco-labels/indices } & $\begin{array}{l}\text { I am interested in how eco-labels \& indices relate to how the clothing } \\
\text { is made }\end{array}$ & .628 & 39.98 & .95 \\
\hline & $\begin{array}{l}\text { It is important to compare between brands that have eco-labels \& } \\
\text { indices to those that don't when I buy a product }\end{array}$ & .584 & & \\
\hline & I think there are too many different eco-labels \& indices & .509 & & \\
\hline & I have a preferred eco-labels \& indices of products and/or brands & .803 & & \\
\hline & I am aware of a particular eco-label \& index for a product and/or brand & .887 & & \\
\hline & I can recognize a particular eco-label \& index of a product or brand & .851 & & \\
\hline & I have heard about a particular eco-label \& index of a product or brand & .815 & & \\
\hline & $\begin{array}{l}\text { I usually read the labels on product packages to see if the contents are } \\
\text { environmentally friendly }\end{array}$ & .825 & & \\
\hline & $\begin{array}{l}\text { I am interested in a company's green campaign and its affects our } \\
\text { environment }\end{array}$ & .635 & & \\
\hline & I prefer to buy brands which promote green campaigns & .600 & & \\
\hline \multirow[t]{6}{*}{ CSR drive } & $\begin{array}{l}\text { I think there are many different types of "green efforts among compa- } \\
\text { nies" }\end{array}$ & .697 & & \\
\hline & $\begin{array}{l}\text { I prefer the green campaigns or programs in the clothing and textiles } \\
\text { industry }\end{array}$ & .587 & & \\
\hline & I have a preferred green program for a product or brand & .627 & 32.40 & .91 \\
\hline & I am aware of a particular green campaign for a product or brand & .814 & & \\
\hline & I can recognize a particular green campaign for a product or brand & .825 & & \\
\hline & I have heard about a particular green campaign for a product or brand & .849 & & \\
\hline
\end{tabular}

$\mathrm{n}=239 ;$ Scale range: $1=$ Strongly disagree; $6=$ Strongly agree

a Factor loading; ${ }^{b}$ explained variance; ${ }^{c}$ Cronbach's $\alpha$

on pro-environmentalism was revealed as highest explanation power, indicating 22 percentage of predictable power $\left(R^{2}=.224\right)$ (See Table 5).

In the testing of Hypothesis 7, eco-label/index (H7a) and CSR drive (H7b) on green purchase intention $\left(F=58.538, p<.001, R^{2}=.0334\right)$ were supported. Hypothesis 8 was also accepted due to the positive influences of Eco-label/index (H8a) and CSR drive (H8b) on recycling $\left(F=10.156, p<.001, R^{2}=.080\right)$. Thus $\mathrm{H} 7$ and 8 were fully supported. Hypothesis 9 was accepted owing to the fact that CSR drive (H9b) positively affected clothing care $\left(F=8.798, p<.001, R^{2}=.070\right)$, which partially supported H9. In the result of the testing of Hypothesis 10, eco-labels/indices (H10a), and CSR drive (H10b) was positively related to eco-citizenship $\left(F=13.537, p<.001, R^{2}=.104\right)$. Hypothesis 11 ( $\left.F=27.549, p<.001, R^{2}=.191\right)$ was accepted due to the positive impacts of eco-labels/ indices (H11a). Hypothesis $12\left(F=23.244, p<.001, R^{2}=.166\right)$ was accepted because eco-labels/indices (H12a) and CSR drives (H12b) were significant. Thus, H10 and 12 were strongly supported while H11 was partially supported. Accordingly, business stewardship of eco-label/index and CSR drives indicated highest percentage of variance $\left(R^{2}=.191\right)$ to predict on fair trade lifestyle practice. In sum, all 12 hypotheses were fully or partially supported, which explain the roles of consumer value and business sustainability in developing consume sustainable lifestyle practices.

\section{Conclusion}

The study concludes that the sustainable VALS framework is pertinent to an examination of the impacts of sustainable value and business stewardship on sustainable lifestyle 
Table 5 Results of multiple regression analysis

\begin{tabular}{|c|c|c|c|c|c|c|c|}
\hline \multirow{2}{*}{$\begin{array}{l}\text { Predictor } \\
\text { variables }\end{array}$} & & \multirow{2}{*}{$\begin{array}{l}\text { Green } \\
\text { purchase } \\
\text { intention }\end{array}$} & \multicolumn{5}{|c|}{ Dependent variables (standardized beta coefficient) } \\
\hline & & & Recycling & $\begin{array}{l}\text { Clothing } \\
\text { care }\end{array}$ & $\begin{array}{l}\text { Eco- } \\
\text { citizenship }\end{array}$ & $\begin{array}{l}\text { Fair } \\
\text { trade }\end{array}$ & $\begin{array}{l}\text { Pro-environ- } \\
\text { mentalism }\end{array}$ \\
\hline \multirow{6}{*}{$\begin{array}{l}\text { Sustain- } \\
\text { able } \\
\text { value }\end{array}$} & Altruistic & $\mathrm{n} / \mathrm{s}$ & $\mathrm{n} / \mathrm{s}$ & $.203^{* *}$ & $.257^{* * *}$ & $.229^{* * *}$ & $.225^{* * *}$ \\
\hline & $\begin{array}{r}\text { Anthropo- } \\
\text { centrism }\end{array}$ & $-258^{* * *}$ & $.210^{* * *}$ & $\mathrm{n} / \mathrm{s}$ & $\mathrm{n} / \mathrm{s}$ & $.127^{*}$ & $.339 * * *$ \\
\hline & $\begin{array}{l}\text { Ecocen- } \\
\text { trism }\end{array}$ & $.157^{*}$ & $\mathrm{n} / \mathrm{s}$ & $\mathrm{n} / \mathrm{s}$ & $\mathrm{n} / \mathrm{s}$ & $.221^{* * *}$ & $.226^{* * *}$ \\
\hline & $R^{2}$ & .097 & .060 & .053 & .076 & .120 & .224 \\
\hline & $\begin{array}{l}\text { Adjusted } \\
\mathrm{R}^{2}\end{array}$ & .086 & .047 & .040 & .064 & .108 & .214 \\
\hline & $F$ & $8.275^{* * *}$ & $4.859^{* *}$ & $4.251^{* *}$ & $6.341^{* * *}$ & $10.411^{* * *}$ & $22.099^{* * *}$ \\
\hline \multirow{5}{*}{$\begin{array}{l}\text { Sustain- } \\
\text { able } \\
\text { stew- } \\
\text { ardship }\end{array}$} & $\begin{array}{l}\text { Eco-label/ } \\
\text { index }\end{array}$ & $.480^{* * *}$ & $.194^{* *}$ & $\mathrm{n} / \mathrm{s}$ & $.149^{*}$ & $.433^{* * *}$ & $.190 * *$ \\
\hline & CSR drive & $.322^{* * *}$ & $.206^{* *}$ & $.255^{* * *}$ & $.286^{* * *}$ & $\mathrm{n} / \mathrm{s}$ & $.360^{* * *}$ \\
\hline & $R^{2}$ & .334 & .080 & .070 & .104 & .191 & .166 \\
\hline & $\begin{array}{l}\text { Adjusted } \\
\mathrm{R}^{2}\end{array}$ & .329 & .072 & .062 & .096 & .184 & .159 \\
\hline & $F$ & $58.539^{* * *}$ & $10.156^{* * *}$ & $8.798^{* * *}$ & $13.537^{* * *}$ & $27.549^{* * *}$ & $23.244^{* * *}$ \\
\hline
\end{tabular}

$\mathrm{n} / \mathrm{s}$ not significant

${ }^{*} \mathrm{p}<.05,{ }^{* *} \mathrm{p}<.01,{ }^{* * *} \mathrm{p}<.001$

practices. Seen from a consumer centric perspective, altruistic, anthropocentrism and ecocentrism values are highly influential determinants on sustainable lifestyle practices. Business stewardship effort in response to the social and environmental movement can facilitate strategic actions to influence consumers' value and belief, as well as to encourage sustainable practices in their everyday lives. As aspects of business stewardship, ecolabels and CSR drives can facilitate consumers' sustainable lifestyle practices.

First, the study empirically supports the claim that sustainable values encourage sustainable lifestyle practices. Altruistic values motivate consumers to help others and raise money for a cause by means of clothing care, eco-citizenship, fair trade and pro-environmentalism because consumers with altruistic values favorably undertake environmental actions (Guagnano et al. 1995). Consequently, altruistic values were highly engaged as eco-citizenship practices by limiting their consumption behavior but purchasing fair trade products. On the other hand, altruistic values' results on green purchase intention were shown insignificant, which could imply that green products were to help other but rather perceive as marketing tools. Furthermore, altruistic and ecocentrism values did not considered recycling as sustainable lifestyle. In other words, a result for recycling were similar to Koch and Domina's (1999) study that information of apparel recycling, accessibility for recycle options, and social norms for recycling could be relatively lacking. Thus, promoting jeans manufactured in an environmentally friendly way from recycled denim (Phau and Ong 2007) can be an effectual strategy which stimulates those consumer groups in favor of the concept of donating clothes for recycling and purchasing products for charity (Dickson 2000). Moreover, anthropocentrism and the ecocentrism values play an important feature in influencing sustainable lifestyle practices. Consumers who think that human beings control the environment believe in anthropocentrism (Nordlund and Garvill 2002). Thus, anthropocentrism values were shown 
to have most significant relationship on recycling and pro-environmentalism, indicating these group were highly opinionated on sustainable lifestyle. However, anthropocentrism and ecocentrism values were not shown relationship on clothing care and eco-citizenship. This result may be because they may have lack of information about clothing care or perceive clothing care as not sustainable lifestyle to environment. Thus, developing an ethical business framework can entice these particular consumers to exert an indirect influence by purchasing less harmful products to environments. Venturing out as the first ethically-driven sneaker brand from sourcing to the final product, Veja is one of few companies becoming successful as an ethical fashion brand (Poldner 2010) by inducing consumers to support protecting the environment as well as to fulfill high fashion sense and desire.

Second, sustainable stewardship significantly affects sustainable lifestyle practices. Eco-labels/indices play a pivotal role in influencing sustainable lifestyle practices. However, clothing care practices were not influenced by eco-label and index. This result shows that eco-label and index do not communicate effectively on clothing care as sustainability, or too many different types of ethical claims about products, such as eco-labels, bio-labels, and social labels (De Pelsmacker et al. 2005), may have caused confusion on the part of consumers and low market penetration (OECD 1997). Similarly, previous studies (Thogersen 2000) have discovered that many companies provide unclear information regarding businesses' ethical or environmental strategies. Recently, HEM, Gap, and Marks \& Spencer have launched a universally-recognized garment labeling scheme, showing the environmental impact of individual garments (DiCamillo 2009). With increasing popularity of eco-labels, it is important to bring both companies and consumers with benefits. From the company's perspective, the labels are expected to address their sustainable practices, and protect it from public regulation while the labeling reduce uncertainty about the environmental performance of products and enable consumers to choose products that cause less damage to the environment and/or help it gain competitive advantages from the consumer's perspective.

The results of this study confirm that the CSR drives significantly increase sustainable lifestyle practices. They suggest that the current CSR drives are influential in producing incremental sustainable value for consumers. If corporations make more efforts in promoting their inimitable CSR drives, it will result in a profit-driven business framework with more purchasing and consumption of their green products. Through these CSR efforts, consumers are induced to endorse more products that seek to conserve our planet or society. Socially conscious consumers are willing to switch brands to support companies and to purchase products because the manufacturer supports charitable causes (Smith and Alcorn 1991). As businesses practice 'cause marketing' and social contribution, socially responsible consumers build a positive image which may result in purchasing decision process. Socially conscious clothing brands such as $\mathrm{So-Me}$ and EDUN help raise awareness for the causes of solidarity and pacifism through fashion products (Poldner 2010). CSR campaigns such as Pink and the Red Hat Society certainly appeal to consumers who are concerned about the benefits for a human group or others' welfare.

With the empirical support for 12 hypotheses, this study provides a comprehensive platform for further analysis of the sustainable VALS approach. However, given the 
study's exploratory nature, there are inherent limitations to generalizing these findings. First, the convenience sampling from students limits the generalization of the research. Although our study was designated to explore college students (median age of 21), future study can explore broader age group by conducting random sampling. Thus, the application of the results from this study can apply to deeper and broader consumer markets, which can help build stronger foundation to understand consumers' sustainable lifestyle practices. Second, the operational constraint surrounding the idea of stewardship creates simplification in integrating the concept of business stewardship into sustainable lifestyle practices. Although this study divided into eco-label/index and CSR drives, both practices had many different definition, and aspects of CSR drives encompasses more than social and environmental responsibility. In this regard, future research can explore different aspects of CSR drives to see dynamic effect on sustainable lifestyle practices. Moreover, future research on sustainable stewardship must develop a sustainable stewardship framework to be applied in sustainable studies. Lastly, instruments from sustainable and other areas of study are restricted in capturing sustainable lifestyle practices focused on the clothing and textile industry. Future research must conceptualize instruments which are specifically related to clothing and textiles to provide further applications and strategies in the clothing and textile industry.

\section{Authors' contributions}

SHNL contributed to develop full manuscript from introduction to future studies. HK guided on direction of manuscript, and structure of manuscript as well as data analysis. KY helped on method of manuscript. All authors read and approved the final manuscript.

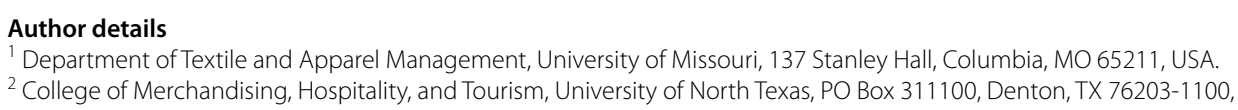

\section{References}

Abdul-Muhmin, A. G. (2007). Exploring consumers' willingness to be environmentally friendly. International Journal of Consumer Studies, 31, 237-247.

Barr, S., \& Gilg, A. (2006). Sustainable lifestyles: Framing environmental action in and around the home. Geoforum, 37, 906-920.

Boston Consulting Group (2012). Millennials pose challenge and opportunity to restaurants, apparel retailers, malls. Retrieved March 14, 2015 from http://www.bcg.com/media/pressreleasedetails.aspx?id1/4tcm:12-120977.

Bruce, C., \& Laroiya, A. (2006). The production of eco-labels. Environmental \& Resource Economics, 36, $275-293$.

Buenstorf, G., \& Cordes, C. (2008). Can sustainable consumption be learned? A model of cultural evolution. Ecological Economics, 67, 646-657.

Bureau of Labor Statistics (2013). Consumer expenditure survey 2013. Retrieved March 24, 2015 from http://www.bls. gov/cex/2013/combined/age.pdf.

Carrigan, M., \& Attalla, A. (2001). The myth of the ethical consumer-do ethics matter in purchase behavior? Journal of Consumer Marketing, 18(7), 560-577.

Chan, R. Y. K. (2001). Determinants of Chinese consumers' green purchase behavior. Psychology and Marketing, 18(4), 389-413.

Chapin, F. S, I. I. I., Carpenter, S. R., Kofinas, G. P., Folke, C., Abel, N., Clark, W. C., et al. (2009). Ecosystem stewardship: Sustainable strategies for a rapidly changing planet. Trends in Ecology \& Evolution, 25(4), 241-249.

Chu, K. M., \& Chan, H. C. (2008). Cross-cultural consumer behavior of general merchandise for Taiwan, Hong Kong, and Shanghai. Business Review, 11(1), 224-230.

Cone Communications (2008). Past, present, future: The 25th anniversary of cause marketing. Retrieved from http://www. coneinc.com/stuff/contentmgr/files/0/8ac1ce2f758c08eb226580a3b67d5617/files/cone25thcause.pdf.

Crane, L. (2007). On campus and beyond: college students today. Harris Interactive-trend \& Trends, 6, 1-4. 
Davidov, E., Schmidt, P., \& SH, Schwartz. (2008). Bringing values back in: The adequacy of the European social survey to measure values in 20 countries. Public Opinion Quarterly, 72(3), 420-445.

De Pelsmacker, P., Janssens, W., \& Mielants, C. (2005). Consumer values and fair-trade beliefs, attitudes, and buying behavior. International Review on Public and Non Profit Marketing, 2(2), 50-69.

DiCamillo, K. (2009). Adidas launches new eco-label: Adidas SLVR. Treehugger.com. Retrieved from http://www.treehugger.com/files/2009/02/adidas-launches-eco-collection-svlr.php.

Dickson, M. A. (1999). US consumers' knowledge of and concern with apparel sweatshops. Journal of Fashion Marketing and Management, 3(1), 44-55.

Dickson, M. A. (2000). Personal values, beliefs, knowledge, and attitudes relating to intentions to purchase apparel from socially responsible businesses. Clothing and Textiles Research Journal, 18(1), 19-30.

Dickson, M. A., Loker, S., \& Eckman, M. (2009). Social responsibility in the global apparel industry. New York: Fairchild Books.

Dietz, T., Fitzgerald, A., \& Schwom, R. (2005). Environmental values. Annual Reviews in Environmental Resources, 30, $335-372$.

Dobson, A. (2003). Citizenship and the environment. Oxford: Oxford University Press.

Emerich, M. (2000). LOHAS means business. LOHAS Journal. Retrieved from http://www.monicaemerich.com/downloads/ lohas_means_business.pdf.

Fairtrade Labelling Organizations International (2010). Growing stronger together: Annual report 2009-10. Retrieved from www.fairtrade.ie/assets/files/FLO_AR_2009.pdf.

Fornell, C., \& Larcker, D. F. (1981). Evaluating structural equation models with unobservable variables and measurement error. Journal of Marketing Research, 18(1), 39-50.

Fraj, E., \& Martinez, E. (2006). Environmental values and lifestyles as determining factors of ecological consumer behavior: an empirical analysis. Journal of Consumer Marketing, 23(3), 133-144.

Gam, H. J. (2011). Are fashion-conscious consumers more likely to adopt eco-friendly clothing? Journal of Fashion Marketing and Management, 15(2), 178-193.

Garrison, S., \& Gutter, M. S. (2010). Gender differences in financial socialization and willingness to take financial risks. Journal of Financial Counseling and Planning, 21, 6-72.

Guagnano, G. A., Stern, P. C., \& Dietz, T. (1995). Influences on attitude behavior relationships, a natural experiment with curbside recycling. Environment and Behavior, 27, 699-718.

Hair, J. F., Anderson, R. E., Tatham, R. L., \& Black, W. C. (1998). Multivariate data analysis (5th ed.). Upper Saddle River: Prentice Hall.

Harcar, T., \& Kaynak, E. (2007). Life-style orientation of rural of US and Canadian consumers: are region-centric standardized marketing strategies feasible? Journal of Marketing, 20(4), 433-454.

Holgar, M., Foth, M., \& Ferrero-Regis, T. (2009). Fashion as a communication medium to raise environmental awareness and stainable practice. Australian and New Zealand Communication Association Conference (pp. 8-10). Brisbane: Queensland University of Technology.

Husted, B. W., \& Allen, D. B. (2000). Is it ethical do use ethics as strategy? Journal of Business Ethics, 27, 21-31.

Joshi, M. (2004). Are eco-labels consistent with world trade organization agreements? Journal of World Trade, 38(1), 69-92.

Kahle, L. R., \& Gurel-Atay, E. (2013). Communicating sustainable for the green economy. New York: M.E. Sharpe Inc.

Karp, D. G. (1996). Values and their effect on pro-environmental behavior. Environment and Behavior, 28(1), 111-133.

Kim, H.-S., \& Damhorst, M. L. (1998). Environmental concern and apparel consumption. Clothing and Textiles Research Journal, 16(3), 126-133.

Kim, H. S., \& Damhorst, M. L. (1999). Environmental attitude and commitment in relation to ad message credibility. Journal of Fashion Marketing \& Management, 3(1), 1-30.

Koch, K., \& Domina, T. (1999). Consumer textile recycling as a means of solid waste reduction. Family and Consumer Sciences Research Journal, 28, 3-17.

Kozar, J. M., \& Hiller Connell, K. Y. (2010). Socially responsible knowledge and behaviors: comparing upper- vs lowerclassmen. College Student Journal, 44(2), 279-293.

Krier, J. M. (2001). Fair trade in Europe 2001: Facts and figures on the fair trade sector in 18 European countries. Research Report for EFTA. Maastricht: European Free Trade Association.

Lachance, M. L., Beaudoin, P., \& Robitaille, J. (2003). Adolescents' brand sensitivity in apparel: influence of three socialization agents. International Journal of Consumer Studies, 17, 47-57.

Margolis, J.D., Elfenbein, H.A., \& Walsh, J.P. (2007). Does It Pay to Be Good? A Meta-Analysis and Redirection of Research on Corporate Social and Financial Performance. Working paper, Haas School of Business, University of California at Berkeley.

McDonald, S., \& Oates, C. (2006). Sustainable: consumer perceptions and marketing strategies. Business Strategy and the Environment, 15, 157-170.

Merchant, C. (1992). Radical ecology: The search for a livable world. NY: Routledge.

Mitchell, A. (1983). The nice American lifestyles. NY: Macmillan Publishing Co., Inc. Mohr, L. A., Webb, D. J., \& Harris, K. E. (2001). Do consumers expect companies to be socially responsible? The impact of corporate social responsibility on buying behavior. Journal of Consumer Affairs, 35(1), 45-72.

Mohr, L. A., Webb, D. J., \& Harris, K. E. (2001). Do consumers expect companies to be socially responsible? The impact of corporate social responsibility on buying behavior. Journal of Consumer Affairs, 35(1), 45-72.

Moon, W., Florkowski, W., Bruckner, B., \& Schonhof, I. (2002). Willingness to pay for environmental practices: Implications for eco-labeling. Land Economics, 78(1), 88-102.

Morgan, L. R., \& Birtwistle, G. (2009). An investigation of young fashion consumers' disposal habits. International Journal of Consumer Studies, 33, 190-198.

Neter, J., Wasserman, W., \& Kunter, M. H. (1985). Applied liner statistical models (2nd ed.). Homewood: Irwin.

Newbery, M., \& Ghosh-Curling, R. (2011). The just-style green report: Ethics, sustainable, Fair trade and corporate social responsibility in the fashion retail and clothing industries: Sustainable: Is the merchandise sustainable? Juststyle: The just-style green report: Ethics, sustainable, 20-29.

Nordlund, A., \& Garvil, J. (2002). Value structures behind pro-environmental behavior. Environment and Behavior, 34(6), 740-756. 
O'Cass, A. (2004). Fashion clothing consumption: antecedents and consequences of fashion clothing involvement. European Journal of Marketing, 38(7), 869-882.

Organization of Economic Cooperation and Development (OECD) (1997). Eco-labeling: Actual effects of selected program. Organization for Economic Co-operation and Development, Paris. 105.

Ottman, J. (1992). Sometimes consumers will pay more to go green. Marketing News, 26(14), 16.

Phau, I., \& Ong, D. (2007). An investigation of the effects of environmental claims in promotional messages for clothing brands. Marketing Intelligence \& Planning, 25(7), 772-788.

Pieters, R., Bijmolt, T., Van Raaij, F., \& de Kruijk, M. (1998). Consumers' attributions of pro-environmental behavior, motivation and ability to self and others. Journal of Public Policy and Marketing, 17, 215-225.

Poldner, K. (2010). Veja: Sneakers with a conscience. Harvard Business Review.

Raghubir, P., Roberts, J., Lemon, K. N., \&Winer, R. S. (2010). Why, when, and how should the effect of marketing be measured? A stakeholder perspective for corporate social responsibility metrics. Journal of Public Policy \& Marketing, 29(1), 66-77.

Schultz, P. W. (2001). The structure of environmental concern: concern for self, other people and the biosphere. Journal of Environmental Psychology, 21, 327-339.

Seckler, V. (2005). Why college students keep spending more. WWD: Women's Wear Daily, 190, 10.

Seligman, C., Olson, J. M., \& Zanna, M. P. (1996). Values: The Ontario Symposium (8th ed.). Hillsdale: Lawrence Erlbaum.

Seyfang, G. (2006). Ecological citizenship and sustainable consumption: Examining local organic food networks. Journal of Rural Studies, 22, 383-395.

Smith, S. M., \& Alcorn, D. S. (1991). Cause marketing: A new direction in the marketing of corporate social responsibility. Journal of Consumer Marketing, 8(3), 19-35.

Soonthonsmai, V. (2007). Environmental or green marketing as global competitive edge: concept, synthesis and implication. In EABR (Business) and ETLC (Teaching) Conference Proceeding, Venice, Italy.

Soyez, K. (2012). How national culture values affect pro-environmental consumer behavior. International Marketing Review, 29(6), 623-646.

Spaargaren, G. (2003). Sustainable consumption: A theoretical and environmental policy perspective. Society and Natural Resources, 16, 687-701.

Steg, L., \&Vlek, C. (1997). The role of problem awareness in willingness to change care use and in evaluating relevant policy measures. In J. A. Rothengatter \& E. Carbonell Vaya (Eds.), Traffic and transport psychology, Theory and application (pp. 465-475). Elmsford: Pergamon.

Steg, L., \& Vlek, C. (2009). Encouraging pro-environmental behavior: an integrative review and research agenda. Journal of Environmental Psychology, 29(3), 309-317.

Stern, P. C., \& Dietz, T. (1994). The value basis of environmental concern. Journal of Social Issues, 50(3), 65-84.

Stern, P. C., Dietz, T., \& Guagnano, G. A. (1995). The new ecological paradigm in social-psychological context. Environmental and Behavior, 27, 723-743.

Stern, P. C., Dietz, T., \& Kalof, L. (1993). Value orientations, gender, and environmental concern. Environment and Behavior, $25,322-348$

Stern, P. C., Dietz, T., Abel, T., Guagnano, G. A., \& Kalof, L. (1999). A value-belief-norm theory of support for social movements: The case of environmentalism. Human Ecology Review, 6(2), 81-97.

Thogersen, J. (2000). Psychological determinants of paying attention to eco-labels in purchase decisions: Model development and multinational validation. Journal of Consumer Policy, 23, 285-313.

Thogersen, J., \& Grunert-Beckmann, S. C. (1997). Values and attitude formation towards emerging attitude objects: From recycling to general, waste minimizing behavior. Advances in Consumer Research, 24, 182-189.

Thørgerson, J., \& Crompton, T. (2009). Simple and painless? The limitations of spillover in environmental campaigning. Journal of Consumer Policy, 32, 141-163.

Thomson, S. C. G., \& Barton, M. A. (1994). Ecocentric and anthropocentric attitudes toward the environment. Journal of Environmental Psychology, 14, 149-157.

van Vugt, M., \& Samuelson, C. D. (1999). The impact of personal metering in the management of a natural resource crisis: A social dilemma analysis. Personality and Social Psychology Bulletin, 25, 731-745.

Vermeir, I., \& Verbeke, W. (2006). Sustainable food consumption: Exploring the consumer "attitude-behavior intention" gap. Journal of Agricultural and Environmental Ethics, 19, 169-194.

Vining, J., \& Ebreo, A. (1992). Predicting recycling behavior from global and specific environmental attitudes and changes in recycling opportunities. Journal of Applied Social Psychology, 22, 1580-1607.

Ward, S. (1974). Consumer socialization. Journal of Consumer Research, 1, 1-13.

Worrell, R., \& Appleby, M. C. (2000). Stewardship of natural resources: Definitions, ethical and practical aspects. Journal of Agricultural and Environmental Ethics, 12(3), 263-277.

Yan, R. N., \& Chang, H. J. (2008). Consumption of low-impact products by Generation Y: Discovery of motives and influential factors. In Paper presented at the International Textile and Apparel Association (ITAA) conference, Schaumburg, IL.

Yeh, N., \& Chen, Y. (2011). On the everyday life information behavior of LOHAS consumers: A perspective of lifestyle. Journal of Educational Media and Library Sciences, 48(4), 489-510.

Zaichkowsky, J. L. (1985). Measuring the involvement construct. Journal of Consumer Research, 12, 341-352. 